\title{
Urban Planning Information Systems and E-Government in Al-Madinah
}

\author{
Yousef A. M. Neyazi \\ Department of Urban and Regional Planning, College of Environmental Designs, King Abdulaziz \\ University, Jeddah 21589, P.O. Box: 80368, Saudi Arabia \\ yneyazi@kau.edu.sa
}

\begin{abstract}
Since last two decades, information systems are widely adopted in all life aspects. In developed world, electronic systems been now shared by government's firms and organizations using Shared- database for managing civic affaires for town, city or in some cases for country for development process worldwide. Moreover they are been adopted even in developing countries such Saudi Arabia in various local governments and Al-Madinah is one of those. These information systems are not applied for just administrative issues, but more for analytical and planning tasks. Such information systems those are used in urban planning are called 'Urban Information Systems' especially the Geographic Information Systems "GIS". This paper reviews literature of urban information systems through three levels: globally, regionally, and locally. Then how this will requires a reform of local governments and municipalities to gain form existing electronic technologies and governmental agencies and bodies, individuals, and public in integrating efforts in developments of cities. More over it explores the case of the project of Al-Madinah e-government'. At last the paper shows how GIS can be used for local planning for future projects, measures forecast, and policy setting. E-government project in Al-Madinah is the first one in Saudi, and will be applied in all over the rest cities. Urban information systems are promising huge capabilities and potentials for efficiency of urban planning in terms of: Public participation, electronic research for urban data, and supporting decision making.
\end{abstract}

\section{Introduction}

In information era, personal computer, email, and Internet are essential tools for most life activities. In urban planning, exchange of digital information became very important and part of process and procedures for decision making. So that Fountain ${ }^{[1]}$ concludes that institutional structures, and their standards, beliefs, norms and values been influenced in new forms of individual's perceptions, interpreting, and application of information technologies. Though, urban planning changed in its processes, techniques, and tools those are used. This might regarded to rapid evolution in hardware and software those dealing with urban complex systems in cities and towns. These systems are called Planning support systems [2,3]. Such technologies brought governments, professionals, and public as parties to participate in planning process in some developed countries such as in Netherlands ${ }^{[4]}$ (McCall 2003) and in UK ${ }^{[5]}$. Fountains 2001, called such use as 'Networked world of the Internet'. He states:

'During most of the 1990's, I assiduously sought out and tracked some of the most important uses of the Internet in the federal government, gaining extraordinary access to the projects and thinking of innovative, deeply committed appointees, senior executives, public managers, and operators. I was surprised to find eerily similar social, organizational, and political effects on their perceptions, design, and use of information systems in the networked world of the Internet.' ${ }^{[1]}$ 
Communications and co-operation between those parties for provision of services are called E-Government. It is widely interested as a technological mode for provision services online. While services provision is a main task of planning authorities and related agencies and organizations, egovernment is the shared systems they all use for such task. Geographic Information System (GIS) is one of the essential technological tool for most agencies and authorities especially those dealing with urban planning. It is well known as super handler system for spatial data, in terms of accuracy of entry, manipulating, analysis, and presentation ${ }^{[6-8]}$. It is also save a lot of time and efforts regarding to traditional manual procedures of such process of planning. GIS as a location based system is the main system that e-government should be based on especially when data can not related to services and utilities in city land.

In Al-Madinah e-government new established, most potential components are afforded for e-government spatial databases ${ }^{[9]}$. For example, digital maps can be used as base of location reference for shared databases. Publics can use their location reference of plot or residential unit as user id for official access for data online or dealing with their own affaires with e-government for civic affaires and neighbourhood amenities.

\section{Urban Planning Information Systems} (UPIS)

Urban Planning Information Systems can be defined as information technologies those are used for city or town planning. Spatial context is an important because of networks of roads, wires and ducts are essentials for the movement of people, goods, facilities and information. Moreover, as Fountain and Vanzil says that major task of urban planning among governments is the provision of services and infrastructure networks. Thus, local governments are always investing in these networks capacity and so, seeking for effective methods of production, distribution and consumption of information for urban life. It is the way governments act during present and future ${ }^{[1,10]}$. Growth of data and information resources is incredible. Though, such information systems and local management systems and governing are needed. Digital maps, e-commerce, and global market, which threats local markets lead to competitive race toward information technology.

By 1990s and the availability of Geographic Information Systems or GIS technology, new era of Urban Planning Information Systems been formed. Mathematic models been linked with spatial information or digital maps, and more analytic tools been extended.

GIS became a general and common tools for most academic fields not only geography but more to other fields such as Planning, environment, and engineering. Thus, in urban planning such systems are called 'Urban Information Systems'. While 'Urban' means spatial or geographic and municipal issues within cities and towns, and information systems means software those are used to manage and manipulates such kind of data ${ }^{[2]}$.

\section{GIS, Applications in Urban Planning}

Globally, geographic information systems (GIS) are widely applied in academic and governmental bodies and become the most applied technologies in municipal governments as same as managing environmental and natural resources, public services, administration and finance, and urban planning ${ }^{[11]}$. (GIS) are used to integrate data from multi resources and for multi purposes and applications. For example Centre of Advanced Spatial Analysis (CASA) used ArcView GIS as a pilot system for the Wandle Valley. The system is used to entry, storage, 
manipulating, and analysis spatial data related to local civic amenities. Moreover, it been used as a tool for public participation workshops and seen as a user-friendly format that enable users to integrates multi-data sets from different sources, for hierarchical suitability, through multi applications and in various presentation forms, then, to provide this service of the project via Internet. Author mentioned that GIS now days are used form strategic planning level of allocating development opportunities to provision of maps for general enquiries. Even though, as analytic tools, GIS functions are basically used to generate buffers zones during planning tasks, to overlaying themes of maps of several socio-economic characteristics, to analyze roads networks, and land suitability ${ }^{[12]}$.

Lotfy Azaz uses GIS and remote sensing for monitoring urban poverty in Alexandria [13] - The researcher use GIS in allocating the most priority areas for new Metro station in the city of Newcastle upon Tyne. He uses socio-economic characteristics in data analysis to allocate most needy areas with easy extension of Metro lines [14]. Ian Masser illustrates three cases studies for use of GIS and remote sensing in urban planning. The first is monitoring urban development process of the city of Villavicencio in Colombia. The second case is for planning task of provision of urban services such as allocating priority areas for health clinics in Dar esSalam in Tanzania. The last is for managing urban planning information in the Lilongwe City Assembly in Malawi funded by World Bank ${ }^{[15]}$.

Regionally, chievements in Middle East are still limited. Only few winners from Middle East were qualified in SAG (Special Achievements in GIS). In 2001, Riyadh Region Water and Sewage Authority (RRWSA) has applied GIS in project with different user interfaces for Hydraulic modelling, maintenance system, call centre, and billing system to the GIS for the whole Riyadh water and sewerage networks (ESRI). Through the last decade, RRWSA integrated an extensive digital maps and database to display the City's entire water and sewer facility network [16]. By 2002, Dubai Department of Civil Aviation (DDCV) uses GIS for management, maintenance, and land use task of airport via web geo-database. Main system includes three subsystems. They are: Pavement management system, utility management system, and layout Management System. Latest software of ArcInfo, ArcView, ArcIMS, and ArcSDE \& DAK were used to build high performance solution of GIS infrastructure.

By 2003 in Kingdom of Bahrain, Municipalities Affairs and Information Systems Directorate (ISD) use GIS as a tool to improve the municipal services of shared spatial information by all the municipalities online. Applications are for building permission, advertising, cleaning, beautification, and urban planning using Arc GIS and ArcIMS (Information Municipal Services) for unifying conflicts of spatial information formats, updating, and reform data for GIS applications.

By 2004 in Qatar, electricity and water department applied GIS in project of network management via intranet applications. Affordability of information for decision makers was difficult before because of multidepartment and multi-data in paper forms of maps. Using web based ArcIMS as GIS applications for data display, query, and analyse network data for better decisions. Software is: ArcIMS 4.01 GIS, ORACLE 8i, and TOMCAT JAVA servlet. But by 2004, only departments of Water/Wastewater in both Saudi Arabia and Abu Dhabi, and Central Information Organisation in Kingdom of Bahrain for economic development has 
qualified as winners for their application of GIS as achievements ${ }^{[16]}$.

Locally, Amanat Al-Madinah (Local Municipality), GIS was adopted since 1993, when author was employee as a planner in Department of Local Planning. An extensive effort by engineer M. Al-Mokharrij (Mayor's Secretary for Deputy of Development and Projects) been done to adopt the system for exact needs and applications in Municipality. A forum been held in Centre of Information and Computer by 1993 and researcher was in technical committee. Selective employees from General Sectors of Urban Planning, Studies and Implementation, and Deployment and Maintenance attended with a team from company of GIS. Forum was to set exact needs and for what application GIS would be in Municipality. New procedures were approved in term of Neighbourhood Planning. Regarding GIS application, Sector of Urban Planning set one of the main regulations during Neighbourhood Planning's process. It was to provide a copy of proposed plan in $\mathrm{CD}$, and drawing should be in CAD, or any GIS format. This step was very forward view for a reform of planning procedures from manual plans to digital ones.

By 1997, Al-Madinah Municipality finished coverage of all Al-Madinah City in Digital Maps. But only by 1998 , the real start of Al-Madinah Municipality in term of GIS applications. Experimental Project of GIS Application in Municipality was conducted by Company of Geographic Technological Visions. Project was finished by 2001 as Khashogji (2002) [17] states that GDB (Geographic Database) which has been built includes all of the layers in 514 Maps; and Spatial Images which cover $1000 \mathrm{~km}^{2}$; Old aerial photos; Minor Municipality's boundaries, Sectors, and districts; 3 dimensional topographic plans; Approved neighbourhood plans; Re-Planning drafts;
Approved subdivided lands; Plans of consultation studies; Plans of road networks; Building's and estate's numbers and codes; Networks of street's lightening, and; Surveys of Tenure deeds.

Proposed applications by Khashogji are classified under the general browser to five main sectors as follows:

A. Deputy of Development and Projects for: surveying, drawing, issuing of Planning exhibit, measuring decision after planning, drawing and naming roads \& streets, site's meta data after planning, permits issuing, fines, projects, valleys drawing, and follow up projects.

B. Deputy of Services for: Lightening, irrigation, sewage of rain water, and cleaning.

C. Minor Municipalities for: control of informal land capture, shop's permits, renewal permits, building fines, health certificates for workers in shops and restaurants, and Haj's permits.

D. General Administration of Coordination and Follow up for: permits of maintenance, and allocating lines of infrastructure pipes or cables.

E. General Administration of Lands: for regularization before planning, after planning, measurement decisions, and land grants.

Khashogji illustrates the main tasks of GIS in Municipality of Al-Madinah: For allocating buildings and numbering them; Establishing of GIS Coding; Evaluating Guidance Plan OF Al-Madinah (1413H/ 1992 AD); and Preparation of Guidance Plan for $(1422-1450 \mathrm{H} / 2001-2049$ AD) referred to approve Urban Spectrum of Al-Madinah. He adds that GIS is a tool that support in process of decision making ${ }^{[17]}$. But he assumes that decisions have only one direction of flow which is top down. The bottom up is left for data flow. He finished that most of difficulties 
to full applications of GIS in Municipality are lack of the followings: system,

1. Buildings' numbering and coding

2. Well skilled stuff,

3. Support from higher commission, and
4. Unified measures and standards for data to be shared.

Thus, when consultant concludes this, then it can be said that GIS applications are still primary and basic ones in term of urban planning in Al-Madinah Municipality. This is called digital gap that most of developing countries have.

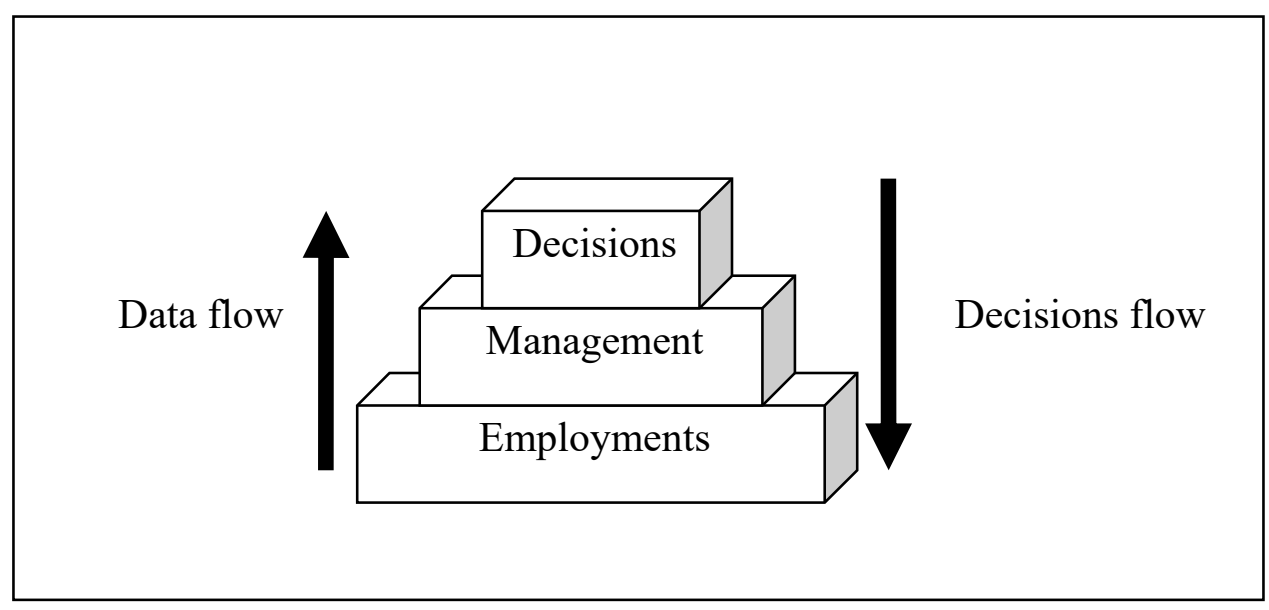

Fig. 1. Data and decisions flow sourced from ${ }^{[17]}$.

\section{Information Technology and Reform of Local Governments}

Information is act of transferring news, data, knowledge, personal study and report; intelligence; knowledge which are gathered from reading, observation, or researching to other. Technology is the scientific or systematic knowledge of the industrial arts and modes those of the more important products either software or hardware ${ }^{[18]}$. Though, information technology is defined as follows:

'Computer hardware and software; voice, data, network, satellite and other telecommunications technologies; and multimedia and application development tools. These technologies are used for the input, storage, processing, and communication of information'. ${ }^{[19]}$

\subsection{Information, Societies, Municipality and Digital Gap}

The real use of Internet stated since 1993. It was the time of change and reform of government in USA which been led by Vice President Al Gore ${ }^{[1]}$. Fountain calls it 'digital government that creates virtual agencies'. Main objective was economic. Clients were individuals and small businesses owners, and government and related organisations were veterans through web portal model that runs 24 hours a day, 7 days a week, and 365 days a year for continuous service in more simple, active, and effective mode. Though he defines a virtual state as:

'A government that is organised increasingly in terms of virtual agencies, cross-agency and public-private 
networks whose structure and capacity depend on the Internet and web'. ${ }^{[1]}$

The result was a virtual world of information, business, management, and planning. Reform of government is not enough and would not be effective without reform of societies. Strambach recommends that for innovative new institutional structures, new form of knowledge should be produced [20]. Kofi Annan states that 'digital gap' exists between most rich and poor countries [21,22], which will leads to influenced gaps in language of afforded information are most in English, needs of rich and poor, gender and access to data, and political or spatial relations as neighboured countries or related companies $^{[23]}$. In general, neglect is there, and gaps increase [22]. Thus Annan recommends decision makers in both governments and businesses with forward view:

"The future of the IT industry lies not so much in the developed world, where markets are saturated, as in reaching the billions of people in the develop world who remain untouched by the information revolution,". [22]

His recommendation is regarded to asses enclosure of the digital gap between developed world and developing one as Turkistani (2004) ${ }^{[21]}$ states. In Global view, telecommunications are narrowing but slow. Highest increases are in the use of mobile phones internet, and electronic answer systems especially in young groups ${ }^{[24]}$. Moreover, slower narrowing in the gap of population size as shown in Fig. 2 \& 3.

Final recommendations of Geneva report (World Summit Information Society (WSIS)) are to face the global challenge in the new Millennium by building the Information Society. Each member is equally share access information to assess the whole community to promote development of its own life quality regarding Human Rights. Though, societies can reduce poverty, increase education, equity of women, improve health, and reserve environment and development for world of peace, just and bloom.

In regional view of 2002, Middle East and Africa, East Europe, and Latin America are the lowest rates of using internet less than $5 \%$. On the other hand, Northern America and Western Europe are the highest rates of $36 \%$ and $28 \%$ consequently. Japan and East Asia are in between with rates of $17 \%$ and $10 \%{ }^{[21]}$ as shown below:

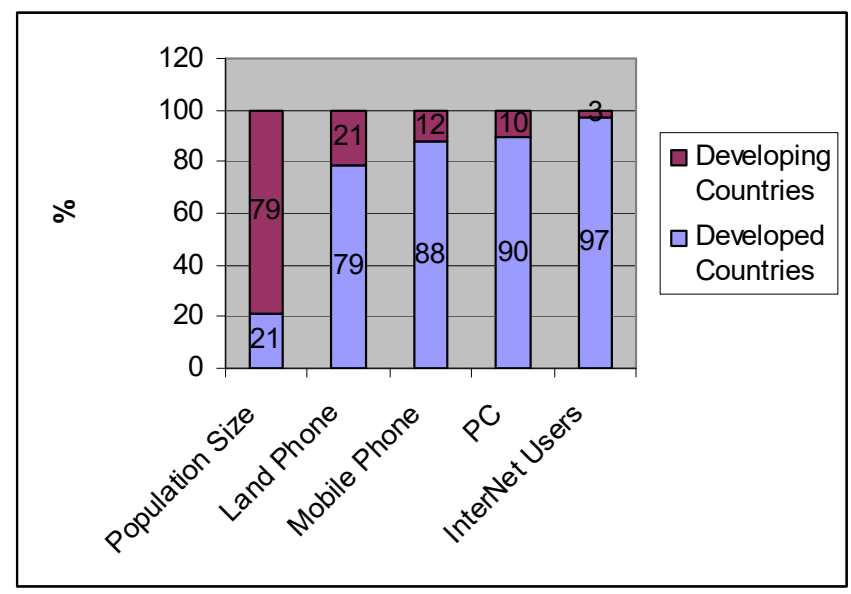

Fig. 2. Digital Gap between Developing and Developed Countries 1992. 


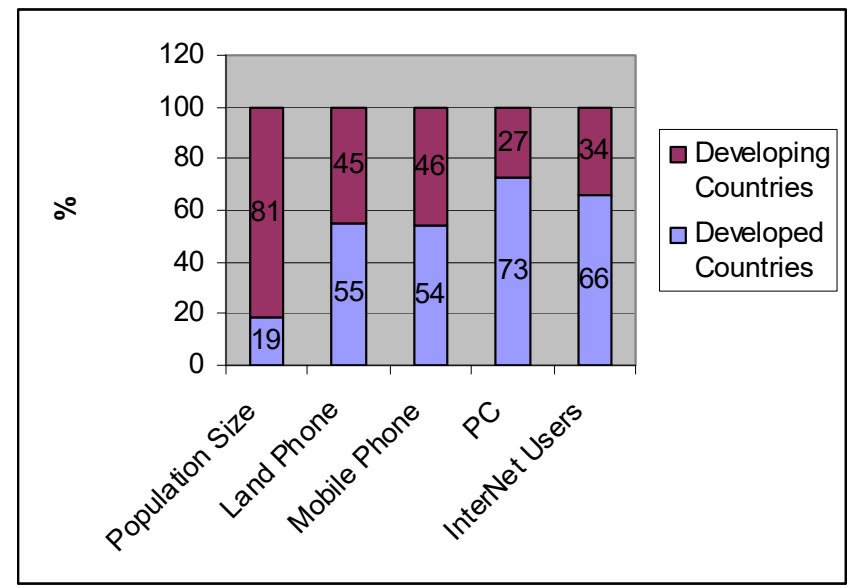

Fig. 3. Digital Gap between Developing and Developed Countries 2002.

Data of both figures sourced from Turkistani (2004) ${ }^{[21]}$, and manipulated by researcher.

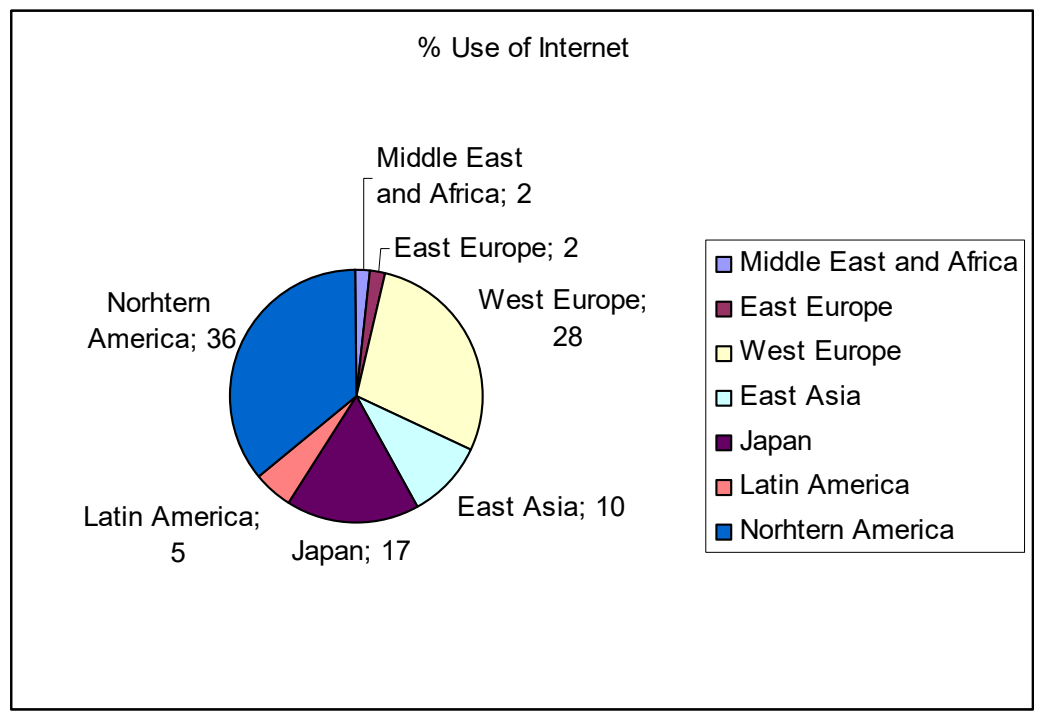

Fig. 4. Percentages of Internet Users over Globe's Regions 2002.

Data sources from Turkistani (2004) ${ }^{[21]}$, and manipulated by researcher

Nationally within Arab Countries in 2000, users of internet in Saudi Arabia are about $2.6 \%$ as the lowest in Gulf Countries, but more than Syria, Yemen, Iraq, and most Arab African Countries except Tunisia. But by 2002 , it increased up to $5 \%$ but still low. Moreover, Saudi has published 8306 authored papers in scientific journals. It is higher than Kuwait, UAE, and Bahrain, and has ratio of $24 \%$ of Arab Region ${ }^{[25]}$.
In 1980, Saudi Arabia percentage of GDP was spent in general education was the highest in Gulf countries except Iran, and less than France, UK, and USA. But in 1995 Saudi spent $5.5 \%$ of GDP higher than most even UK and USA, but less than France and Kuwait. By 1999, Saudi is the highest of all. By 2001, Saudi is almost the lowest percentage in access to internet except Iran as shown in table below [25]. 
Table. 1. Public Spending on Education \% of GDP, and \% access to internet.

\begin{tabular}{|l|ccc|l|}
\hline & $\mathbf{1 9 8 0}$ & $\mathbf{1 9 9 5}$ & $\mathbf{1 9 9 9}$ & $\mathbf{2 0 0 1} \%$ Internet Users \\
\hline $\begin{array}{l}\text { Saudi } \\
\text { Arabia }\end{array}$ & 4.1 & 5.5 & $\mathbf{7 . 5}$ & 1.34 \\
\hline UAE & 1.3 & 1.9 & 1.9 & 33.92 \\
Kuwait & 2.8 & $\mathbf{6 . 1}$ & 6.5 & 10.1 \\
Bahrain & 2.8 & 3.6 & 3.7 & 19.88 \\
Iran & 7.5 & 4.1 & 4.6 & 0.62 \\
France & 4.9 & 6 & 5.9 & 26.37 \\
UK & 5.6 & 5.2 & 4.7 & 39.95 \\
USA & 6.6 & 5.2 & 5 & $\mathbf{4 9 . 9 5}$ \\
\hline
\end{tabular}

Source: Data sourced from Keivani, et al. (2003) ${ }^{[25]}$, and manipulated by author

While fund for education in Saudi is high, and access to internet is low, Turkistani (2004) ${ }^{[21]}$ was very honest when illustrating causes of the digital gap in Saudi Arabia. He states that situation of Information Technology and Systems in governmental bodies is limited because of the followings:

- Unstressed on use of PC's in fields of planning, control, statistical analysis, and decision making,

- Not updated systems in term of capacity for more extra digital information and tasks,

- Limited use of PC's on draft printing, salary's statements, and old documents storage,

- Lack of Information Knowledge in employees,

- Widespread of fragmented independence information networks without connection between departments within one firm, and

- Not been planned for study of actual and future multi needs before purchasing current hard and soft wares..
But all these difficulties should not stop our move forward. Governmental efforts to close down this digital gap are running, and public's efforts should integrate them. The first is the strategic goals of the Seventh Development Plan as shown before in Chapter Four. The goal is to development of information sector, and communication as first priorities. The second is the national plan for information technology. Then, form many committees to study issues of electronic trade and government. Then, establishing a ministry and trust those deal with information technology and telecommunications. Last is availability of most governmental firms in Saudi Arabia on internet's websites ${ }^{[21]}$. But, this is not enough where Healy et al. (1997) ${ }^{[26]}$ argues that for Automating governments, they need to redistribute responsibilities between local government, agencies and organisations. But they had problems such as difficulties coupled with data use and capture, and the restructuring of the actor's systems by the information systems.

\subsection{Reform to Electronic Municipality}

Electronic municipality is a new approach for municipality that works digitally using computer networks of internet for most their services and activities. As shown above that local governments start to provide most services electronically as done in South Africa Municipality ${ }^{[10]}$. Despite negative points of digital gap between age groups, it is a global wave that moves all governments, and then they should solve their local communities and adjust their own standards for their exact needs. The roles of radical shifts in information technology affect and reform urban context. Physical connects and local identity may be lost regarding to access to everything, any time, and any where ${ }^{[27]}$. AlKodmany states that technology advancements give planners potentials to: Visualise limitless information, and participate with publics for 
planning views and ideas during planning process. He concludes that for high technology planning system, 'Genuine partnerships between computer experts (municipalities, businesses, universities, individuals) and grass-roots organizations are imperatives, [28]. It is also been stated that for successful development of information in urban planning process, the need is for co-ordination between decision makers structures and virtual spaces [29]. Thus, it is required for establishing community networks as base for three phases of virtual development. The phases are design, primary growth, and most recent one ${ }^{[30]}$. Al-Kodmany (2000) ${ }^{[31]}$ states that GISbased community digital system is been used for neighbourhood planning. The systems enhanced communication between planners, publics, and community groups in landscape planning ${ }^{[20]}$. Wieman states that major shift in government's methodologies in term of infrastructure planning. He adds that rather than reduction in costs, new technologies allow remote working in task $\mathrm{s}$ of: Environment regulations, land use planning, and demand management in more efficiency [32].

Though, local governments and municipalities directed by global wave of information technology to act for planning in new form of service provision, decision making, co-operation structure, and tools used for such tasks of planning. But unlikely to "utopian-futurism", to leave all our problems to progress of technology, Luithlen (1998) ${ }^{\text {[3] }}$ states that critical analyses are the most needed through processes of planning and impact on urban context, community, and society. He cited some words of Castlells that say:

"However, this transformation of the mode of development could not be accomplished without the surge of innovation in information technology which, by creating the material basis from which information processing can expand its role, contributes to the change both in the infrastructure of production process, and in organization of society". [33]

In regional level between Arab cities, shows cases studies of electronic municipalities within Arabic Institute for Developing Cities. He concludes program's goals as follows ${ }^{[34]}$ :

- Improve capabilities of cities and municipalities in term of information technology.

- Improve potential's skills of Arabic cities and municipalities for IT.

- Partnership private sector in the process of IT development of Arabic cities.

- Provide scientific literature and references for Arabic cities in term of IT.

$\mathrm{He}$ state that main issues are for transforming from manual works to electronic works and services via internet, mobile, and emails. Then he gives example of establishing electronic portals for municipalities such as Al-Madinah Portal. Recent Arabic successes are firstly in sector of electronic government is shown with example of Dubai, Musqat, Amman, and Sana'a ${ }^{[33]}$. He states that goals to be achieved by short plan are: to develop technical infrastructures those are bases for electronic services; provide electronic civic services via internet; prepare application faster and accurate than before; reduce visits of clients to civic offices for applications; and to improve and enhance internal procedures for such applications as Al-Kodmany (2001) [28] states to be as simple as. Al-Hayajnah then, illustrates the goals of long terms plans as: Provide the maximum number of civic services via internet $(80 \%)$; provide services through maximum devises such as mobile phone, laptops, and notepads; continuous 
stress to enhance internal procedures to support electronic services, and improve IT Knowledge upon clients, and employees to benefit from such services.

\subsection{Case of Amanat Al-Madinah (Al- Madinah Municipality)}

In evaluating the case of Al-Madinah Municipality (Amanat Al-Madinah), Turkistani, who is the General Manager of Management Development, argues that previous situation in terms of organizing, manpower management, and improving application of PC's in the firm's level as a 4/5 level of satisfaction. Each employee had only one direct manager and hierarchal as a sequence. Control and management of activities, and conflicts is well controlled. Healy et al. (1997) ${ }^{[26]}$ states in term of information technology and management control that information systems are used for rational and economical support for socioeconomic policies, but should not be for gaining more central power and control. Then he states that ratios of control in term of methodology of management. In personal management rate is $32.5 \%$ and similar ratio in shared work as a team, but in democratic management rate is a bit more with $35 \%$. The sample size was 120 within the Municipality employees. Thus, the first effort to close the digital gap in Municipality is to Plan within the firm's framework, where previously most works were prepared without plans of frameworks, and in general they are personal efforts. Thus, training workshop was run including leaders of Municipality for setting View, Statements, and Strategic Goals. The Municipality's view for Al-Madinah is:

'To be a religion Centre characterized by its own identity, and in the same time to be a modern city with integrated services'. [21]

But, its statement is:
'We love Al-Madinah, and will provide special civic services with high quality to achieve comprehensive development with partners, to reserve our environment sustainable, and to be sincere with our values'. [21]

Strategic goals were not differ much from strategic principals of the Seventh Development Plan those are shown in Chapter Four. He states that Municipality set specific strategic goals within the firm's framework as follows:

- Afford appropriate work environment, and improve capabilities, and skills of Municipality's employees,

- Personalize the civic services; deep improving of public's knowledge,

- Reserve Al-Madinah's personal identity; and adopting services via electronic devices as 'Digital Municipality' to improve action processes from traditional to reactive ones,

- Reconstruct the Municipality's Framework of employees with restudy tasks and responsibilities of each department, reset the outline of job process, and adopting 'integrated quality' in al services, and

- Integration and co-operation with other organizations to achieve integrated provision of services and exchange experiences.

But in term of manpower, he says that the Municipality set strategic principals in term of choosing and employment as follows:

- Increase educational level of employees by training programs, provision of PC's to Municipality's employees, and set the real needs of skills for training programs. 


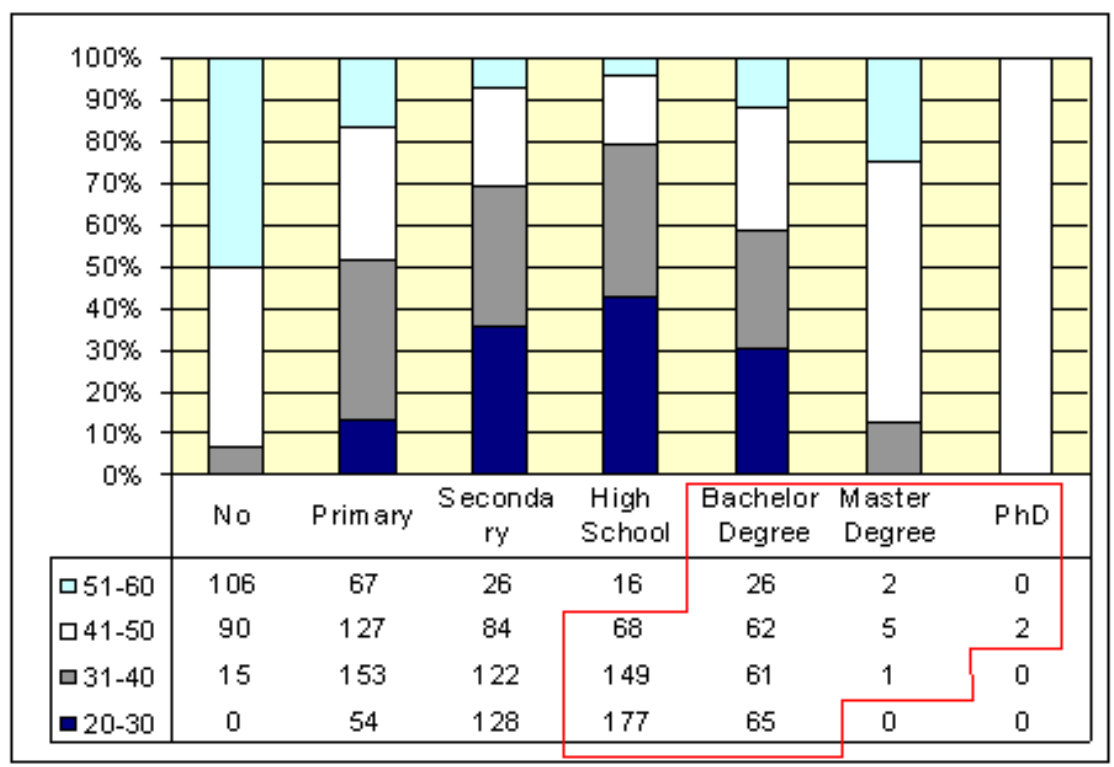

Fig. 5. Education Level in Municipality's Employees and Ages (2002)

Data sourced from Turkistani (2004) ${ }^{[21]}$, and manipulated by author.

Because of only 2 employees have PhD's, and 8 have Masters, the rest of course, have lower education. Thus, digital gap is there and emergence solution to close is more education and training.

Figure 5 shows that the ratio of those over 50 's is about $15 \%$ of total employees, and highest percentage of them is with no primary education $(50 \%)$. But at this group there are two having Masters, but lowest in others levels compared to other groups. On the other hand, the group of (31-40) has the highest ratio with $31.2 \%$ of total employees. But groups of (20-30) and (41-50) have a bit over quarter each. Group of (20-30) has the highest numbers of those having certificates of secondary school, high school, or bachelor degrees, but the lowest in Master or $\mathrm{PhD}$. Though, priorities of training programs should be for those having high school education in groups under 50's, and those having bachelor degrees, masters, and $\mathrm{PhD}$ 's in all groups as lined around in the table within Fig. 5.
These employees seem as potentials for fast benefit and updating information for closing up the digital gap and preparing for the new challenge of electronic government. On the other hand, those having low education should not be neglected, but they should have introductory courses about IT, benefits and its applications as a step forward to get better understanding for how to gain from electronic services and how provision would be. Then, those are fresh graduated planners should be training in more advance GIS applications to support them in urban planning task, using census data and multi resources data regarding others services and amenities.

Municipality of Al-Madinah did huge effort in closing this administration digital gap as Turkistani (2004) ${ }^{[21]}$ states. Between 1421 $1424 \mathrm{H}$ (2000-2003), it granted about 20 scholarships, and sent 421 employees for learn in and out, and sent 368 employees for training in General Administration Institute. But he does not mention at what level of 
education those granted been allocated and whether there were a repetitions of same employees.

In term of Organisation itself, he firstly recommends that procedures, processes, should be simplified, and all organising lists, procedures, instructions, and publications had to be classified as a step for entry in computer through the Municipality website (http://www.amana-md.gov.sa). Then he follows recommending that all operation models should be engineered and adoption of Work Flow System on application's follow up apply idea of 'Unified Reception Offices'. He states that activate electronic archive, and electronic cards are essential for development of administrative system, and electronic mail (email) for publications, and calls for meetings to develop administrative communications. For future's main plans of Municipality to gain all solutions needed at level of electronic government he suggests the followings:

- Apply of 'Change Management' by end of year to integrate with project of E-Gov. and sustain its achievement.

- Qualify all employees to get certificate of ICDL 'International Computer Driving Licence', using remote education, and then for more specific programs.

- To establish a local training centre for Al-Madinah as a global level by co-operation with educational partners to cover all parts of the city, and all fields and subjects.

Such co-operation is the key issue for integrated efforts as start for increase information knowledge of all citizens. Such knowledge is a leading for social change that will qualify such bodies, firms, and organizations to furnish the basic infrastructure for such huge project. Moreover, publics can be then able to participate more efficiently in process of decision making of planning of their own neighbourhoods.

The key issue here is lack of using new technology in term of management of urban planning. Then, the gap between local government and utility agencies and organisations still needs to be closed more in term of inter co-operation.

Nevertheless, public don't participate in planning process to issues those they related to especially building regulations. Thus, in the developed countries technological innovation is an essential tool for science, methods and urban planning. Though, the institutional inter-relationships should be considered during the processes of adoption and using the new technology as E-Government Project at AlMadinah. Healy et al. (1997) ${ }^{[26]}$ states that main consideration should be taken in mind are: how these inter- relations between local governments and other institutions should be? Then, what data they can share from the database? And last what are categories of those user actors? She illustrates that applications of UPGIS among coherent of many actors have some difficulties. First is the scale, which each actor uses for such application. So, keeping up large-scale data the databases will cost more than expected. Second is the systems which were used for data collection might be not compatible with UPGIS. Thus, standardising and unifying the UPGIS are essentials for those actors dealing with planning processes, because UPGIS has the ability to integrate various types of data. Nevertheless, its capacity for forecasting and modelling systems is based on the accuracy of data and the use of models. Indeed, computerised systems are most accurate in term of data entry, storage, manipulating, analysis and evaluation, but the errors are lie on the methodologies of use by the actors themselves. Thus, she states that: 
'The data system must be adapted constantly to the phenomenon or process being studied, and the illusion of universality which increasingly more powerful systems are capable of creating is a permanent trap. The managers and decision-makers in our cities must be made more aware of these risks', ${ }^{[26]}$ (pp: 159-162).

Before UGIS is being adopted, there are two requirements. The first is for reorganising the urban boundaries. This, because of UGIS with can handle technical and administrational boundaries. But, the most important during the adoption of the system is the continuously updating of data by each partner. This means that database is a common resource, which each partner has equal access to it. The second is for reorganising the actors. Models of relationships and inter-relations of actors are essentials for adoption UGIS.

\section{PPGIS: Public Participation Geographic Information Systems in Planning Process as A task of E-Government}

\subsection{Preface}

As shown above that Information technology now is an essential tool for maintaining efficiency of planning operation. Moreover, it changes and requires reform of procedures, and process of planning task within the new coming e-government. Adoption of GIS within E-Government is an essential base for most activities especially urban planning. While MIS is used as a tool for operation management, GIS should be employed as tool for public participatory system that used during electronic research (Eresearch) within planning process as a decision support system. Internet is a virtual space that occupied by such live and continuous communication system. E-Government is a project of electronic website that responds to public's needs, views, and interests, and then provides most services electronically. In this subchapter, author intends to set conceptual framework of how publics can participate in future planning system via GIS-Based EGovernment.

\subsection{Public Participatory System}

During chapters 6 and seven, it is shown that most building regulations and neighbourhood's amenities are far from public actual needs. Though, public should strongly participate in planning process. Nevertheless, information technology furnishes bases with capabilities such as virtual meeting; 24 hours claim system, email system, and visual communications. On the other hand, GIS has capabilities of presenting data more simply to publics that they can understand easily and then participate in planning process. Actors of participation are planners, decision makers, community organisation's members, and citizens. M. Mahmoud (2004) ${ }^{[35]}$ states that participated solutions tend to be reasonable, realistic, and sustainable. She mentions that scale of community is varies between neighbourhood, to town, or city. This community member can be as official firm that negotiate with government. She shows approaches those should be in GIS for public participation. First, it should enhance public's participation via web based GIS as simple and easy as possible. Then, right of accessibility to GIS data. Then, public's input, and interaction during process of decision making. Last, integration between internet and GIS ${ }^{[35]}$. As a result she states; participation can minimise future's problems.

Though in term of building regulations, public's participation will determines both quality and quantity of dwellings those most people needs rather than those only developers need. Previous two chapters show clearly how public's views, ideas, arguments, and proposals can assist and enhance decisions of 
building regulations. Quantity is also determined by funds from governments, loans, and citizen's savings. It is easy to answer when publics seems valued to governments in term of participation as ${ }^{[36]}$. Simply, when they became as customers and governments as agencies compete with others to benefit from maximum citizens.

Moreover, participation is as activity of citizenship in democratic form via current frameworks of government as done in UK experiment [37]. They state that criteria to perform democracy of citizenship through egovernment would be through six steps. They are: Public opinions, goals of public's policy, feedback systems, consultative processes, transformation, reform of policy making in government, and democracy of public's participation via web-based GIS. Laterasse and Pauchard believe that future of GIS should be a tool to enhance spatial management and potential part of reforming local democracy ${ }^{[26]}$. So, project of E-Government should adopt maximum participation system within planning processes and using the modern technologies to achieve such goals.

\subsection{E-research for Urban planning using GIS}

GIS based web systems are widespread as a tool for data collection and entering using location based system. Data collection builds up database using GIS especially with Internet or Web-GIS. Integration of data from multisources, relating them with location based maps (digital maps) enrich database for eresearch. For example if census data tells that specific district had high density of single labour, planning for schools will not give this district a priority for new schools. In contrast, if census data tell families with children under 7 years old are heavily concentrated in such district or neighbourhood, planning department will give a high priority of new kindergartens. Moreover, high recommendation then would consider traffic separation between walk ways and transport modes. Of course, these processes will take long time in old techniques, but won't take more than minutes using electronic systems those link multisources of data with maps that show availability of amenities around specific areas. So, Web-GIS would be an essential tool for modern planner and department of planning within E-Government that integrates public's views with other information for task of urban planning.

\subsection{GIS and Decision Support system (DSS)}

Whereas e-research of urban planning enables planners and other decision makers integrate various data from multi-sources, a decision support system is an extra tool that allows powerful help in final data manipulation and decision stage. This will allows for many alternatives and scenarios to be examined ${ }^{[38]}$. GIS is considered as the twin of DSS regarding to powerful components of interface, database, and modelling as stated by Husain and Eid (2004) and Al-Garni (2004) [39,40]. They and Mahmoud (2004) ${ }^{[35]}$ mention how GIS can be used as analytical tool for modelling to support decision making in various scenarios. They mention that spatial analysis of GIS effectively support planners, researchers, and decision makers in process of urban planning for sustainable development. GIS is seen as a tool for DSS in term of evaluation of multi scenarios of solutions for each problem by using prediction, simulation, and modelling. Thus, Farag states that GIS is a visual analytical part of models for planning support systems ${ }^{[41]}$. She illustrates that GIS is not enough as single but should be coupled with others traditional analytical tools for planners such as social and economic once. She mentions 'INDEX' as GIS-based planning support system in term of land-use and design decision within planning process. She 
illustrates in Fig. 2 the framework of INDEX MODEL as follows:

First stage is set up the database as areas and studies. Second is allocation of study area such as neighbourhood descriptions or proposals. Then, elements of studies should be regarded to indicators or standards such as land-uses, transportation, housing, and infrastructure. Then, scoring and weighting rates of importance and priority. Then, case comparison between alternatives by charts, and maps. Last is final visualising to actors. Actors may be stakeholders as governments, planners, decision makers, or publics who participate in planning process. This final stage may use three dimension model, video display or photos, and links to internet with other network ${ }^{[41]}$. But, as Chauhan (2004) ${ }^{[42]}$ states that many organizations are using GIS only few of them use its maximum powerful. Though, GIS is a tool that can be used as decision support system but it should be used in professional form of applications in term, map drawing, data analysis, presentation, and in modelling for better solutions with multiscenarios and alternatives ${ }^{[42]}$. The main decision support system should be gain by consideration of public views regarding to planning issues those affect their life within cities and within their neighbourhoods. Of course, adoption of GIS as an essential tool will achieve such objectives via internet networks and project of E-Government.

\section{Conclusion}

While E-Government is widespread as promising IT applications for telecommunications between governments, business, and citizens, it is a hope for equity, transparency, and participatory system for planning the future. Al-Madinah local government has lunched EGovernment as the first project in Saudi Arabia. Potentials exists in Al-Madinah governments firms and services authorities.
Fragmented efforts in separate websites are very clear. Similarity of information exists in many websites with no integration for what user really need and lack. Service and shopping online are still very basic limited. The best are the electronic bill payment for services such as electricity, telephone, and banks via internet or through cash machines. Huge efforts and funds are essentials, and self fund for such project is not enough.

GIS technology as location based systems should be main part of data bases those e-government and others firms integrated their efforts regarding to share data for future planning. Shared GIS databases enable governments and related firms for better research (self entry data collection, analysis with co-operation, participatory process of decision making, and setting local regulations and policies those fit citizens needs.

This paper is not to evaluate egovernment project of Al-Madinah, but rather it is to give attention to GIS capabilities as location based system that can implement better applications. Moreover, Al-Madinah local governments firms such as Amanat Al-Madinah, has already applied GIS for municipal affaires. With co-operation and integration data and information between maximum firms, authorities, and companies, E-government project can stand on solid base of IT to provide services, amenities, and needs those are citizens are currently lacking. Nevertheless, GIS based e-government may shape future of the city and people live in with safe, secure, economic, social, and cultural life.

\section{References}

[1] Fountain, J. E. (2001). Building the Virtual State. Washington, D. C., Brookkings Institution Press.

[2] Brail, R., R. Klosterman, et al. (2001). Planning 
Support Systems. Resland, California, ESRI Press.

[3] Davis, D. E. (2003). GIS for Everyone. Redlands, California, ESRI Press.

[4] McCall, M. K. (2003). "Seeking good governance in participatory-GIS: A review of processes and governance dimensions in applying GIS to participatory spatial planning." Habitat International, 27(4): 549-573.

[5] Williams, P. B. (2003). "Evaluating electronic local Governemt in the UK.", Journal of Information Technology: 22.

[6] Goodchild, M. F. and Parks, B. O. (1993). Environmental Modeling with GIS. New York, Oxford University Press.

[7] Goodchild, M. F. (1999). Interoperating Geographic Information Systems. Boston, Kluwer Academic Publishers.

[8] Goodchild, M. F. (1996). GIS and environmental modeling: Progress and Research Issues. Fort Collins, CO, GIS World Books.

[9] Al-Madinah Local Government (2004). Electronic gate for Al-Madinhah; (E-Gov).

[10] Vanzil, H. (2004). Municipalities Act's Development for implementation of Strategic Plan for Electronic Government in South Africa, Amanat Al-Madinah 'Al-Maidnah Municipality', 2004.

[11] Esnard, A. M. (1998). "Cities, GIS, and Ethincs", Urban Technology, 5(3): 33-45.

[12] Centre for Advanced Spatial Analysis CASA (1999). London's Brownfield Resource Pilot Project: The Wandle Valley. London, CASA: Centre for Advanced Spatial Analysis: 1-39.

[13] Azaz, L. K. A. (1997). Map of Urban Poverty in Alexadria. Gepgraphy. Menofia, Menofia University, Faculty of Arts: 355.

[14] Neyazi, Y. A. (1999). Metro Network in Newcastle City: using ArcView GIS for. Deaprtment of Town and Country Planning. Newcastle upon Tyne, Newcastle University: 90.

[15] Masser, I. (2001). "Managing our urban future: the role of remote sensing and geographic information systems". Habitat International, 25: 503-512.

[16] The Economic and Social Research Institute ESRI (1995-2004). Special Achievement in GIS, Published in the ESRI. 2004.

[17] Khashogji, N. A. (2002). Project of GIS Applications in Al-Madinah Municipality 'Arabic'. Al-Madinah, Amanat Al-Madinah Al-Monawarah 'The Electronic Municipality'. 2004.

[18] Brainy Media (2001). Brainy Dictionary,
BrainyMedia.com. 2004.

[19] National Council for Accreditation of Teacher Education NCATE (1997). Glossary of NCATE Terms, NCATE. 2004.

[20] Strambach, S. (2002). "Change in the Innovation Process: New Knowledge Production and Competitive Cities:The Case of Stuttgart." European Planning Studies, 10(2): 215-231.

[21] Turkistani, M. A. G. (2004). Case Study of AlMadinah Municipality in Application of E-Gov Principals 'Arabic'. Al-Madinah/ SA, Amanat AlMadinah Al-Monawarah 'The Electronic Municipality'. 2004.

[22] Blau, J. (2003). UN Delegates Meet to Close the 'digital gap', IDG News Service. 2004.

[23] Wilkinson, K. (2004). "Lnagauge Difference and Communication Policy in the Information Age." The Information Society, 20(3): 217-229.

[24] Dulude, L. (2002). "Automated telephone answering systems and aging." Behaviour \& Information Technology, 21(3): 171-184.

[25] Keivani, R., A. and Parsa, A. (2003). "Development of ICT Sector and Urban Competitivness: The Caes of Dubai." Journal of Urban Technology, 10(2): 19-46.

[26] Healey, P., S. Cameron, et al. (1997). Managing Cities; The New Urban Context.

[27] Page, S. and B. Phillips (2003). "Telecommunications and urban design: Representing Jersey City." City, 7(1): 73-94.

[28] Al-Kodmany, K. (2001). "Visualization Tools and Methods for Participatory Plannng and Design." Journal of Urban Technology, 8(2): 1-37.

[29] Macdonald, K. I. (2000). "Use and Valuation: Information in the City." Urban Studies, 37(10): 1881-1892.

[30] Cindio, F. D. and Gentile, O. (2003). "Community Networks: Rules of Behavior and Social Structure." The Information Society, 19: 395-406.

[31] Al-Kodmany, K. (2000). "GIS in the Urban Landscape: reconfiguring neighbourhood planning and design processes", Landscape Research, 25(1): 5-28.

[32] Wieman, C. (1998). "The High-Tech Transition: Technology and the Prospects for Improving Infrastructure Performance", Journal of Urban Technology, 5(2): 21-46.

[33] Luithlen, L. (1998). "The Gravity of Information: A New Order of Cities and the Role of Urban Planners." Journal of Urban Technology 5(2): 61-77. 
[34] Al-Hayajnah, A. F. (2004). Electronic Municipalities: Arabic and International cases 'Arabic', Arabic Cities Organisation. Sep 2004.

[35] Mahmoud, M. (2004). Sustainable Development Using GIS Web based Public Participation in Urban Planning. The Role of GIS Services in the EGovernment: ITI Fifth Arab Conference on Geographic Information Systems (Arab Map 2004) 6-7 September, Cairo, Eygpt, Infromation Tehcnology Institute.

[36] Osborne, D. and Gaebler, T. (1993). Reinventing Government. London, Penguin Books Ltd.

[37] Barbatt, C. (1996). Management Strategy and Information Technology. London, International Thomson Business Press.

[38] Jones, D. S. and Crowe, B. (2001). Transformation not Automation; The e-government challenge. London, Demos.

[39] Husain, E. M. and Eid, M. A. (2004). The role of GIS in Processes of Desision Support to Allocation of New Development Areas 'Arabic'. The Role of GIS Services in the E-Government: ITI Fifth Arab
Conference on Geographic Information Systems (Arab Map 2004) 6-7 September, Cairo, Eygpt, Infromation Tehcnology Institute.

[40] Al-Garni, A. M. (2004). Web Based GIS Demand and Constraints The KSU Case. Third International Conference and Exhibition GIS 2004, 27-29 September, The Diplomat Radison SAS, Kingdom of Bahrain, The bahrain Society of Engineers.

[41] Farag, J. S. (2004). GIS Models Measuring Community Sustainability. The Role of GIS Services in the E-Government: ITI Fifth Arab Conference on Geographic Information Systems (Arab Map 2004) 6-7 September, Cairo, Eygpt, Infromation Tehcnology Institute.

[42] Chauhan, A. (2004). GIS Based Decision Making Model for Planning in Multi-Level Highway Dveleopment Organization. The Role of GIS Services in the E-Government: ITI Fifth Arab Conference on Geographic Information Systems (Arab Map 2004) 6-7 September, Cario, Eygpt, Infromation Tehcnology Institute. 


\section{نظم معلومات التخطيط الحضري والحكومة الإلكترونية في المدينة المنورة}

\section{يوسف عبدالكبير محمد نيازي}

قسم التخطيط الحضري والإقليهي، كلية تصاميم البيئة، جامعة الملك عبدالعزيز، ص.ب: 80368، جدة. 21589، المملكة

\section{العربية السعودية}

yneyazi@kau.edu.sa

الهستخص. خلال العقدين الماضيين، تم إدراج نظم المعلومات بشكل واسع في شتى نواحي الحياة. ففي العالم المتقدم، تشاركت المؤسسات الحكومية والمنظمات النظم الإكترونية باستخدام قواعد البيانات المشتركة لإدارة الثؤون المدنية بالمدن والقرى، وفي بعض حالات الأرياف لعملية التنمية بشكل واسع. كما استخدمت هذه النظم في العالم الماضي في طور النمو، ومنهم المملكة العربية السعودية في العديد من الحكومات المحلية (إمارات المناطق) وإحداها كانت إمارة منطقة المدينة المنورة. ولم تقتصر تطبيقات هذه النظم المعلوماتية فقط على المهام الإدارية، بل أكثر من ذلك لتثمل تحليلات مهام التخطيط الحضري. وتسمى تلك النظم المستخدمة في التخطيط الحضري ب "نظم التخطيط الحضري"، وبالأخص نظم المعلومات الجغرافية (GIS). ويهتم البحث بمراجعة أدبيات نظم المعلومات العمرانية من خلال ثلاثة مستويات: العالمي، والإقليمي، والمحلي. ثم معرفة كيفية التحول للإدرات المحلية، والبلديات للاستفادة من التقنيات الإلكترونية الحالية بالهيئات، والأجهزة الحكومية، والمجتمع في تكامل الجهود لتنمية المدن. وينتهي البحث بعرض لكيفية استخدام نظم المعلومات الجغرافية (GIS)، في الحكومات المحلية للتخطيط المحلي للمشاريع المستقبلية، والتتبؤ بالمؤشرات التحليلية، وإعداد الأنظمة والسياسات. فمشروع الحكومة الإكترونية في المدينة كان الأول في في في في السعودية، والذي سيتم تطبيقه في بقية الددن. إن نظم المعلومات العمرانية واعدة بالكثير من القدرات والإمكانات لفعالية التخطيط العمراني، بما يخص مشاركة العامة، والبحث الإلكتروني للمعلومات الحضرية، وعملية صنع القرار • 